\title{
United States multicenter study of factors predicting the persistence of GH deficiency during the transition period between childhood and adulthood
}

Charmian A Quigley ${ }^{1 *}$, Anthony J Zagar ${ }^{1}$, Charlie Chunhua Liu², David M Brown ${ }^{3}$, Carol Huseman ${ }^{4}$, Lynne Levitsky ${ }^{5}$, David R Repaske ${ }^{6}$, Eva Tsalikian ${ }^{7}$ and John J Chipman ${ }^{8}$

\begin{abstract}
Background: Many patients with childhood-onset growth hormone $(\mathrm{GH})$ deficiency do not fulfill diagnostic criteria for GH deficiency (GHD) after attainment of adult height and may not require long-term GH treatment. Patients with history of idiopathic GHD (IGHD) pose the greatest management dilemma, as data regarding factors predictive of persistent GHD in this group are lacking.

Objectives: The objective of this study was to assess potential predictors of persistent GHD in a US patient cohort during transition from childhood to adulthood, particularly in patients with history of IGHD.

Methods: We studied 73 US patients with history of childhood-onset GHD screened at 21 US pediatric endocrine centers for a randomized clinical trial of $\mathrm{GH}$ replacement after attainment of adult height. The cohort comprised 42 boys/men and 31 girls/women aged14-22 years, who had received $\geq 1$ year of GH treatment and had completed linear growth. The main outcome measures were sensitivity, specificity, positive and negative predictive values (PPV, NPV) of clinical and hormonal factors for persistent GHD (defined a priori in this study as peak $\mathrm{GH}<5 \mu \mathrm{g} / \mathrm{L}$ ).

Results: For the cohort as a whole, the best predictors of persistent GHD (100\% PPV) were history of organic hypothalamic-pituitary disorder or $\geq 2$ additional pituitary hormone deficiencies (PHD). Best predictors of persistent GHD in patients with childhood history of IGHD were standard deviation scores (SDS) for serum insulin-like growth factor binding protein-3 (IGFBP-3) below -2.0, and for insulin-like growth factor-I (IGF-I) below -5.3 (measured $\geq 6$ weeks after completion of GH treatment; PPV 100\% for both), and age <4 years at original diagnosis (PPV 89\%). IGFI above -1.6 SDS had 100\% NPV.
\end{abstract}

Conclusions: US patients with an organic cause of childhood-onset GHD or $\geq 2$ additional PHDs may not require GH stimulation testing to reconfirm GHD after completion of childhood treatment. In contrast, patients with idiopathic childhood-onset GHD almost invariably require retesting, as GHD persists in only a minority (those who were very young at initial diagnosis and those who have subnormal IGFBP-3 or extremely low IGF-I after completion of childhood treatment). Subnormal posttreatment IGF-I (<-2.0 SDS) lacked predictive power for persistent GHD, whereas IGF-I > -1.6 SDS was 100\% predictive of GH sufficiency.

Keywords: Transition, Growth hormone deficiency, Hypopituitarism, Predictive value of tests, Child, Adolescent, Adult, Idiopathic

\footnotetext{
* Correspondence: qac@lilly.com

'Lilly Research Laboratories, Indianapolis, IN 46285, USA

Full list of author information is available at the end of the article
} 


\section{Background}

Growth hormone $(\mathrm{GH})$ treatment of patients with $\mathrm{GH}$ deficiency (GHD) diagnosed in childhood has historically focused on maximizing adult height. However, this limited goal overlooks the importance of GH for completion and maintenance of somatic and metabolic maturation, including bone mineralization; accrual of lean body mass, with accompanying increases in muscle strength and exercise capacity; and changes in lipid metabolism [1-18]. Thus, there is now consensus that GH replacement is important for those patients with childhood-onset GHD who remain GH deficient after completion of linear growth [18-22].

Pharmacologic GH stimulation testing is generally recommended to confirm the diagnosis of persistent GHD during the childhood-to-adulthood transition, but this procedure requires interruption of $\mathrm{GH}$ therapy, is labor intensive, and is logistically challenging, given the scarcity of testing agents now available. In addition, provocative testing is invasive, has the potential for significant side effects, and produces inconsistent results that do not predict treatment response [19-24]. Because of these issues, several European studies have examined clinical and biochemical predictors of persistent GHD [25-30]. However, interpretation of the data is affected by factors such as the retrospective nature of most studies, interstudy differences in diagnostic criteria, and interassay variability. Furthermore, because previous studies have been performed in Europe, where diagnostic and treatment practices differ from US practices, the existing data may not be directly applicable to the largest group of children treated in the USA - those with idiopathic GHD (IGHD). Therefore, this study determined the prevalence of persistent GHD after attainment of adult height in a cohort of US childhood-onset GHdeficient patients during the transition period, with particular focus on those with IGHD, and examined the value of various factors as diagnostic predictors of persistent GHD.

\section{Methods}

\section{Patients}

This study screened 73 patients at 21 US institutions for entry to a randomized clinical trial of GH effects on bone and body composition in previously treated childhoodonset GH-deficient patients (efficacy and safety data have been reported $[12,15])$. The study was approved by the institutional review boards of participating institutions, and written informed consent was obtained from patients and/ or their legal guardians.

Study entry criteria included: age 14-28 years; diagnosis of GHD during childhood/adolescence (either idiopathic or organic [i.e. due to a genetic or structural cause]); $\mathrm{GH}$ treatment $\geq 1$ year, completed 6 weeks -5 years before screening; attainment of adult height (height velocity $<1$ $\mathrm{cm} /$ year); no history of spinal or total body irradiation, bone dysplasia, or significant systemic illness. Patients with additional pituitary hormone deficiencies (PHDs) were required to have received stable replacement therapy (thyroxine, glucocorticoids, sex steroids, vasopressin, as needed) for $\geq 6$ months. The US cohort from this international study was selected for the analysis reported here because serum $\mathrm{GH}$, insulin-like growth factor-I (IGF-I), and insulin-like growth factor binding protein-3 (IGFBP-3) concentrations for all US patients were measured at a central laboratory.

Baseline demographic data included etiology and age at diagnosis of childhood GHD, duration of previous GH treatment, presence of additional PHDs, age, and height and weight at retesting.

\section{Assessment of $\mathrm{GH}$ secretion}

Screening for entry to the adult GH replacement trial included IGF-I and IGFBP-3 measurements followed by $\mathrm{GH}$ stimulation testing. A single stimulation test was sufficient for patients with history of multiple PHDs (MPHD); 2 tests were required for patients with history of isolated GHD. Protocol-preferred stimulation tests included insulin tolerance test (ITT), combined arginine/L-dopa test, and glucagon test. However, to represent the breadth of US pediatric endocrine practice, no specific testing protocol was mandated. Patients were eligible to enroll in the GH replacement trial if IGF-I was $<1^{\text {st }}$ percentile for age/sex and peak GH was $<5 \mu \mathrm{g} / \mathrm{L}$. The GH threshold for definition of GHD was specified a priori in the protocol and is consistent with guidelines for diagnosis of GHD during the transition period [19-21]. Data from all US patients are included in this report, regardless of eligibility for the GH replacement trial.

\section{Laboratory analyses}

IGF-I was measured by an IGFBP-blocked radioimmunoassay as described elsewhere (sensitivity $0.1 \mu \mathrm{g} / \mathrm{L}$; intraand interassay coefficients of variation $[\mathrm{CV}], 1.6 \%$ and $6.4 \%$, respectively [31]). IGFBP-3 was measured by radioimmunoassay (sensitivity $0.13 \mathrm{mg} / \mathrm{L}$; intra- and interassay CV, $1.9 \%$ and 9.2\%, respectively [32]). Results were converted to standard deviation scores (SDS) using data for age/sex-matched controls from the same assays. GH was measured using an immunochemiluminometric assay specific for 22-kDa human GH [33]. All assays were performed centrally at Esoterix Endocrinology, Inc (Calabasas Hills, CA, USA).

\section{Statistical analyses}

Statistical analyses were performed using the SAS software system (SAS Institute, Inc, Cary, NC). Because stimulated $\mathrm{GH}$ values were not normally distributed, the 
nonparametric Wilcoxon test was used to evaluate differences between GH-deficient vs. non-GH-deficient patients with respect to number of additional PHDs, serum IGF-I/IGFBP-3, age at original diagnosis, weight, and body mass index $\left(\mathrm{BMI} ; \mathrm{kg} / \mathrm{m}^{2}\right)$. The difference in peak $\mathrm{GH}$ among patients with $0,1, \geq 1$, or $\geq 2$ PHDs was examined using the nonparametric Kruskal-Wallis test. Relationships between peak $\mathrm{GH}$ and potential explanatory variables were assessed using Spearman correlation coefficients $\left(r_{s}\right)$. Summary data for continuous variables are presented as mean \pm SD unless otherwise noted.

\section{Calculation of sensitivity, specificity, positive predictive} value, and negative predictive value

Sensitivity, specificity, positive predictive value (PPV), and negative predictive value (NPV) were calculated to determine the utility of clinical and laboratory variables as screening tests for persistent GHD (defined as peak $\mathrm{GH}$ response $<5 \mu \mathrm{g} / \mathrm{L}$ ). Screening variables included etiology of childhood GHD (organic vs. idiopathic), age at childhood diagnosis, number of additional PHDs, and study entry values for weight, BMI, IGF-I, and IGFBP-3. Continuous variables (age, weight, BMI, IGF-I, and IGFBP-3 SDS) were tested to determine cut-off values predictive of GHD. Patients with values beyond the cutoff were classified as having a positive screening test (screen) for GHD. Patients with a positive screen who had maximum $\mathrm{GH}<5 \mu \mathrm{g} / \mathrm{L}$ were designated as true positive (TP); patients with a positive screen who had peak $\mathrm{GH} \geq 5 \mu \mathrm{g} / \mathrm{L}$ were designated false positive (FP); a negative screen accompanied by peak $\mathrm{GH} \geq 5 \mu \mathrm{g} / \mathrm{L}$ was defined as true negative (TN); a negative screen with peak $\mathrm{GH}<5 \mu \mathrm{g} / \mathrm{L}$ was defined as false negative (FN).

The following additional definitions were used: sensitivity (of the screening test), represent the probability of a positive screen among patients with GHD (i.e. proportion of GH-deficient patients correctly identified by the screen, calculated as $\mathrm{TP} /[\mathrm{TP}+\mathrm{FN}])$; specificity, the converse of sensitivity, represents the probability of a negative screen among non-GH-deficient patients (proportion of nonGH-deficient patients correctly identified by the screen; $\mathrm{TN} /[\mathrm{TN}+\mathrm{FP}]) ; P P V$, is the probability of GHD among patients with a positive test (proportion of patients with positive screen who were $\mathrm{GH}$ deficient; $\mathrm{TP} /[\mathrm{TP}+\mathrm{FP}])$; $N P V$, is the probability of being non-GH deficient among patients with a negative screen (proportion of patients with negative screen who were non-GH deficient; TN/ $[\mathrm{TN}+\mathrm{FN}])$. These calculations were determined for all patients (organic and idiopathic combined) and repeated separately for patients with IGHD.

\section{Results}

Historical and demographic data

Of 73 patients (42 male, 31 female; ages 13.7-22.4 years), 18 had history of organic GHD, and 55 had history of IGHD (Figure 1, Table 1). Organic causes of GHD included craniopharyngioma $(n=6)$, glioma $(n=3)$, astrocytoma $(n=2)$, germinoma $(n=2)$, cranial irradiation $(n=2) ; 1$

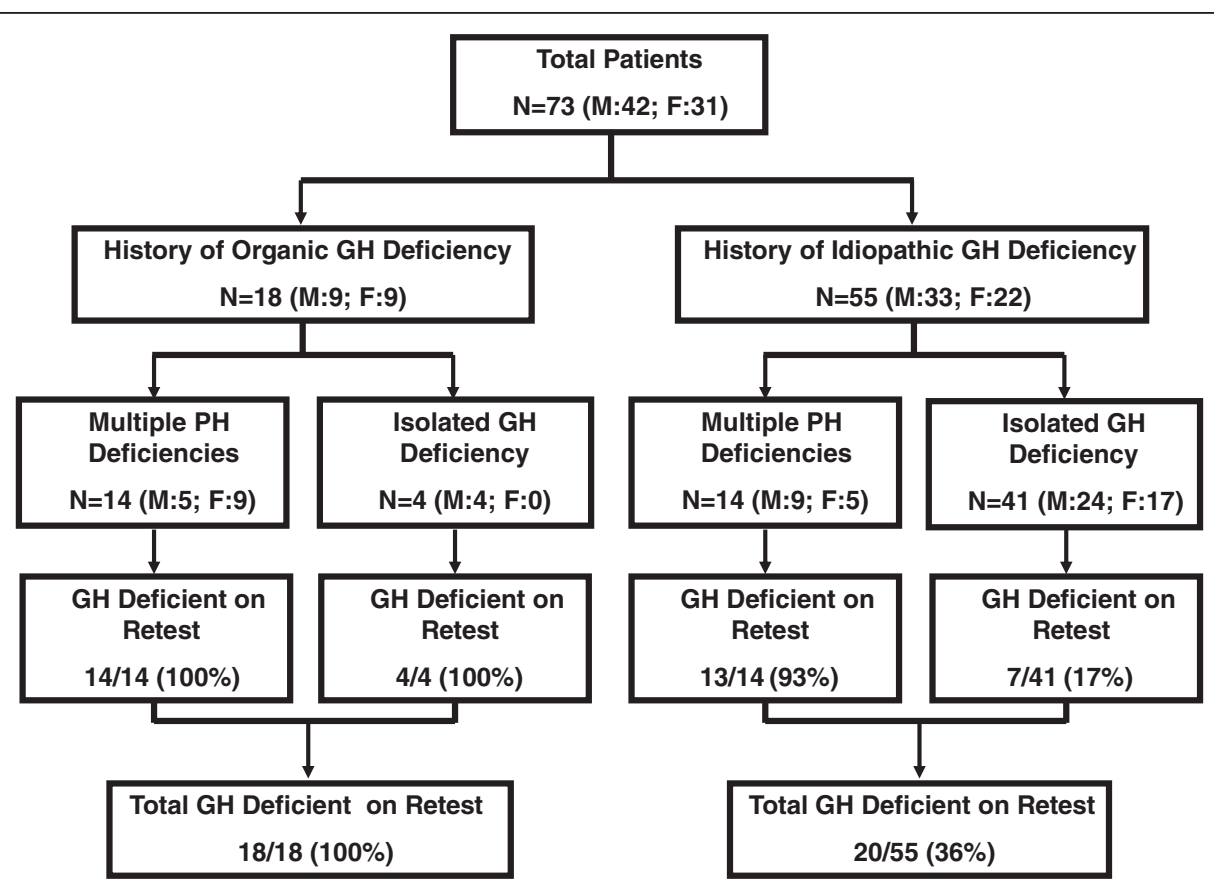

Figure 1 Participant flow diagram. Participant flow diagram of patients included in this study, showing numbers with history of organic vs. idiopathic GH deficiency, multiple pituitary hormone deficiencies vs. isolated GH deficiency, and numbers with confirmed GH deficiency on retesting. $\mathrm{F}=$ female; $\mathrm{GH}=$ growth hormone; $\mathrm{M}=$ male; $\mathrm{N}=$ number of patients; $\mathrm{PH}=$ pituitary hormone. 
Table 1 Demographic and diagnostic data

\begin{tabular}{|c|c|c|c|c|c|c|}
\hline \multirow[b]{2}{*}{ Variable } & \multicolumn{3}{|c|}{ GHD at retest (peak $\mathrm{GH}<5 \mu \mathrm{g} / \mathrm{L}$ ) } & \multirow{2}{*}{$\begin{array}{l}\text { Non-GHD at retest* } \\
\text { All patients } n=35 \\
\text { (M:20; F:15) }\end{array}$} & \multicolumn{2}{|l|}{$p$ values** } \\
\hline & $\begin{array}{l}\text { Organic } n=18 \\
\text { (M:9; F:9) }\end{array}$ & $\begin{array}{l}\text { Idiopathic } n=20 \\
\text { (M:13; F:7) }\end{array}$ & $\begin{array}{l}\text { Total } n=38 \\
(M: 22 ; F: 16)\end{array}$ & & $\begin{array}{l}\text { All: GHD vs. } \\
\text { non-GHD }\end{array}$ & $\begin{array}{l}\text { Idiopathic: GHD vs. } \\
\text { non-GHD }\end{array}$ \\
\hline $\begin{array}{l}\text { n (\%) patients with } \\
\text { isolated GH deficiency }\end{array}$ & $4(22)$ & $7(35)$ & $11(29)$ & $62(89)$ & & \\
\hline \multirow[t]{2}{*}{ Age at diagnosis $(\mathrm{yr})^{1}$} & $10.0 \pm 2.2$ & $4.5 \pm 3.2$ & $7.1 \pm 3.9$ & $10.5 \pm 3.3$ & $<0.001$ & $<0.0001$ \\
\hline & $10.6(6.3,13.7)$ & $4.6(0.1,11.6)$ & $7.2(0.1,13.7)$ & $11.0(2.2,16.9)$ & & \\
\hline \multirow[t]{2}{*}{ Age at retest (yr) } & $17.9 \pm 2.2$ & $17.6 \pm 1.8$ & $17.7 \pm 2.0$ & $17.0 \pm 1.6$ & 0.08 & 0.17 \\
\hline & $18.2(14.1,22.4)$ & $17.6(13.7,21.9)$ & $17.6(13.7,22.4)$ & $16.7(14.1,20.2)$ & & \\
\hline \multirow{2}{*}{$\begin{array}{l}\text { Duration of childhood } \\
\text { GH treatment (yr) }{ }^{1}\end{array}$} & $5.6 \pm 2.9$ & $11.4 \pm 3.6$ & $8.6 \pm 4.4$ & $5.5 \pm 2.8$ & $<0.01$ & $<0.0001$ \\
\hline & $4.6(2.0,11.8)$ & $12.2(3.1,16.7)$ & $8.1(2.0,16.7)$ & $4.7(1.4,12.7)$ & & \\
\hline \multirow[t]{2}{*}{ Time off GH (yr) } & $1.7 \pm 1.6$ & $1.5 \pm 1.0$ & $1.6 \pm 1.3$ & $0.9 \pm 0.6$ & 0.01 & $<0.01$ \\
\hline & $1.2(0.1,5.0)$ & $1.4(0.2,4.2)$ & $1.3(0.1,5.0)$ & $0.7(0.2,2.2)$ & & \\
\hline \multirow[t]{2}{*}{ Weight (kg) } & $76.9 \pm 18.8$ & $75.5 \pm 19.7$ & $76.2 \pm 19.0$ & $60.5 \pm 10.0$ & $<0.001$ & $<0.01$ \\
\hline & $74.6(44.9,119.3)$ & $69.8(47.1,110.5)$ & $74.2(44.9,119.3)$ & $59.2(42.5,82.4)$ & & \\
\hline \multirow[t]{2}{*}{ BMI $\left(\mathrm{kg} / \mathrm{m}^{2}\right)$} & $27.5 \pm 6.2$ & $26.4 \pm 5.5$ & $26.9 \pm 5.8$ & $21.9 \pm 2.9$ & $<0.001$ & $<0.01$ \\
\hline & $26.8(15.1,37.4)$ & $26.2(18.6,37.4)$ & $26.2(15.1,37.4)$ & $21.0(16.6,29.8)$ & & \\
\hline \multirow[t]{2}{*}{ BMI SDS } & $0.9 \pm 1.6$ & $0.9 \pm 1.2$ & $0.9 \pm 1.4$ & $0.1 \pm 0.9$ & $<0.001$ & $<0.01$ \\
\hline & $1.4(-4.4,2.5)$ & $1.4(-1.8,2.5)$ & $1.4(-4.4,2.5)$ & $0.2(-2.3,1.9)$ & & \\
\hline \multirow{2}{*}{$\begin{array}{l}\text { Number of additional } \\
\text { PHDs }\end{array}$} & $2.3 \pm 1.7$ & $1.5 \pm 1.4$ & $1.9 \pm 1.6$ & $0.0 \pm 0.2$ & $<0.0001$ & $<0.0001$ \\
\hline & $2.5(0.0,4.0)$ & $1.5(0.0,4.0)$ & $2.0(0.0,4.0)$ & $0.0(0.0,1.0)$ & & \\
\hline \multirow[t]{2}{*}{ Peak GH ( $\mu \mathrm{g} / \mathrm{L})$} & $0.7 \pm 0.9$ & $0.5 \pm 0.6$ & $0.6 \pm 0.8$ & $15.2 \pm 10.1$ & $<0.0001$ & $<0.0001$ \\
\hline & $0.2(0.1,3.0)$ & $0.3(0.0,2.2)$ & $0.2(0.0,3.0)$ & $13.0(5.0,57.0)$ & & \\
\hline \multirow[t]{2}{*}{ IGF-I ( $\mu \mathrm{g} / \mathrm{L})$} & $100 \pm 67$ & $123 \pm 78$ & $112 \pm 73$ & $309 \pm 123$ & $<0.0001$ & $<0.0001$ \\
\hline & $86(30,265)$ & $95(20,248)$ & $93(20,265)$ & $295(117,738)$ & & \\
\hline \multirow[t]{2}{*}{ IGF-I SDS } & $-6.2 \pm 2.4$ & $-5.7 \pm 2.7$ & $-6.0 \pm 2.5$ & $-1.9 \pm 1.4$ & $<0.0001$ & $<0.0001$ \\
\hline & $-6.0(-9.8,-1.6)$ & $-5.8(-11.1,-1.6)$ & $-5.8(-11.1,-1.6)$ & $-2.0(-5.3,1.5)$ & & \\
\hline \multirow[t]{2}{*}{ IGFBP-3 ( $\mu \mathrm{g} / \mathrm{L})$} & $2.5 \pm 1.0$ & $2.8 \pm 1.3$ & $2.7 \pm 1.2$ & $3.8 \pm 0.7$ & $<0.0001$ & $<0.01$ \\
\hline & $2.5(1.1,4.5)$ & $2.4(1.1,5.9)$ & $2.5(1.1,5.9)$ & $3.8(2.5,5.4)$ & & \\
\hline \multirow[t]{2}{*}{ IGFBP-3 SDS } & $-1.4 \pm 1.6$ & $-1.2 \pm 1.9$ & $-1.3 \pm 1.7$ & $0.4 \pm 0.8$ & $<0.0001$ & $<0.01$ \\
\hline & $-1.3(-4.5,1.2)$ & $-1.4(-4.6,2.4)$ & $-1.3(-4.6,2.4)$ & $0.4(-1.2,1.9)$ & & \\
\hline
\end{tabular}

Values are means \pm SD and median (minimum, maximum). ${ }^{*}$ All patients who retested as non-GH deficient had idiopathic GH deficiency in childhood. ${ }^{* *} \mathrm{p}$ values for comparisons of groups who were GH deficient vs. non-GH-deficient at retest were obtained from nonparametric Wilcoxon tests. ${ }^{1}$ Comparisons between organic vs. idiopathic patients with GHD at retest: $p<0.0001$ for age at diagnosis and duration of childhood GH treatment; all others, nonsignificant. Abbreviations: $B M I=$ body mass index, $F=$ female, $G H=$ growth hormone, $G H D=G H$ deficiency, $I G F-I=$ insulin-like growth factor $I, I G F B P-3=$ insulin-like growth factor binding protein $3, \mathrm{~kg}=$ kilogram, $M=$ male, $m^{2}=$ meters squared, $n=$ number, $P H D s=$ pituitary hormone deficiencies, $S D S=$ standard deviation score, $y r=$ year.

patient each had a history of medulloblastoma, septo-optic dysplasia, and pituitary hypoplasia.

Twenty-eight of 73 patients $(38 \%)$ had $\geq 1$ additional PHD (14/18 [78\%] organic; 14/55 [25\%] idiopathic). In order of prevalence these were: thyroid-stimulating hormone (TSH, $n=25$ [34\%]); gonadotropins ( $\mathrm{n}=20$ [27\%]); adrenocorticotropic hormone $(n=17$ [23\%]); vasopressin $(\mathrm{n}=10$ [14\%]). Eight patients (11\%) had 1 additional PHD, 5 (7\%) had 2 additional PHDs, 6 (8\%) had 3 additional PHDs, and 9 (12\%) had 4 additional PHDs. The relationship between additional PHDs and likelihood of persistent GHD is reported below.

\section{$\mathrm{GH}$ stimulation retest results}

The following GH stimulation tests were performed: arginine/L-dopa (48/73 [66\%]); arginine alone (11/73 [15\%]); ITT alone (7/73 [10\%]); ITT/arginine (3/73 [4\%]); 1 patient each was tested with ITT/clonidine, ITT/L-dopa, L-dopa alone, and an unspecified test. As shown in Figure 1 and Table 1, 38 of 73 patients had peak $\mathrm{GH}<5 \mu \mathrm{g} / \mathrm{L}$ at retest (male, 22/42 [52\%]; female, 16/31 [52\%]; organic, 18/18 [100\%]; idiopathic, 20/55 [36\%]); 37/38 (97\%) patients with persistent GHD had severe GHD, with peak $\mathrm{GH}<2.5 \mu \mathrm{g} / \mathrm{L}$. Of 20 patients with history of childhood IGHD confirmed as having 


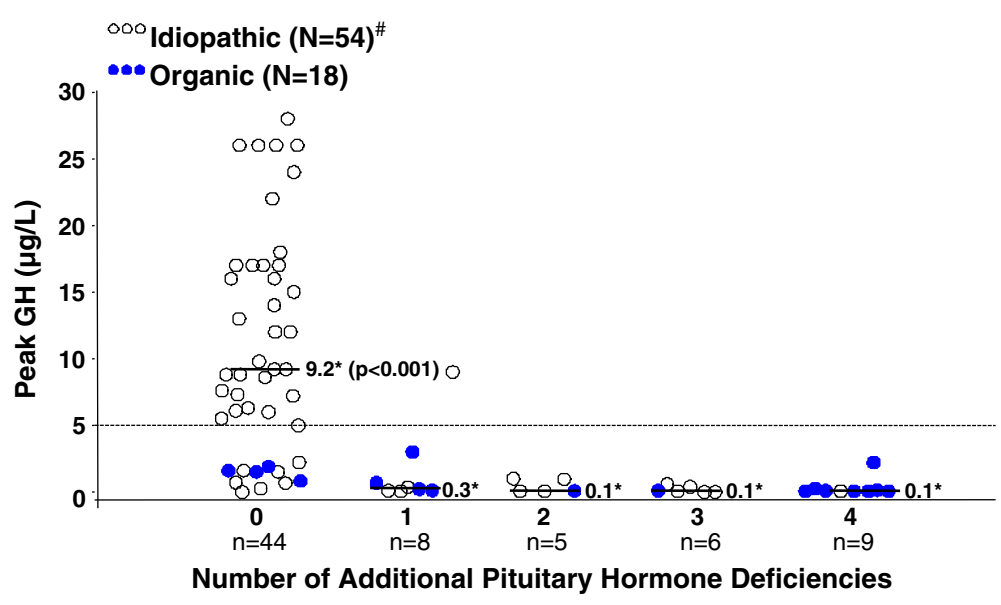

Figure 2 Peak GH response according to number of additional pituitary hormone deficiencies (PHD). Horizontal lines represent the median values of the peak stimulated $\mathrm{GH}$ concentrations for patients with 0, 1, 2, 3, and 4 additional PHDs; ${ }^{*} p<0.0001$ for comparison of medians for the group with isolated GH deficiency (no additional PHDs) vs. all others. See "Results" for listing of stimulation tests used. "To avoid compressing the vertical axis, $1 \mathrm{GH}$ value of $57 \mu \mathrm{g} / \mathrm{L}$ (idiopathic patient) is not shown. $\mathrm{GH}=$ growth hormone; $\mathrm{N}=$ total number of patients in each category (organic vs. idiopathic); $n=$ number of patients in each subgroup.

persistent GHD $(\mathrm{GH}<5 \mu \mathrm{g} / \mathrm{L})$, only 3 patients had peak $\mathrm{GH}$ values $>1.0 \mu \mathrm{g} / \mathrm{L}$ at retest $(1.5,1.6,2.2 \mu \mathrm{g} / \mathrm{L})$. Patients with persistent GHD were younger at original diagnosis than those not reconfirmed as $\mathrm{GH}$ deficient, and at screening were significantly heavier and had lower posttreatment serum IGF-I and IGFBP-3 (Table 1).

\section{Predictors of persistent GH deficiency All patients}

The strongest predictor of persistent GHD was history of organic hypothalamic-pituitary disorder: 18/18 organic patients retested as $\mathrm{GH}$ deficient (100\% PPV) vs. $20 / 55(36 \%)$ of those with history of IGHD. However, sensitivity was low (47\%) because history of IGHD did not preclude persistent GHD.

The second highly predictive finding was the presence of additional PHDs (Figure 2, Table 2). Of 28 patients with $\geq 1$ additional PHD, 27 (96\%) had $\mathrm{GH}<5 \mu \mathrm{g} / \mathrm{L}$ at retest (13/ 14 [93\%] idiopathic, 14/14 [100\%] organic). Overall, GHD was reconfirmed in $24 \%, 88 \%, 96 \%$, and $100 \%$ of patients with $0,1, \geq 1$, and $\geq 2$ additional PHDs, respectively (PPV
$100 \%$ for $\geq 2$ PHDs; Table 2). Peak stimulated GH ( $\mu$ g/L) was significantly lower in patients with $\geq 1$ additional PHD than in those with isolated GHD (mean \pm SD, median, range: $0.7 \pm 1.8,0.1,0.0-9.0$; vs. $11.9 \pm 10.8,9.2,0.0-57.0$; $\mathrm{p}<0.001$ ). However, presence of additional PHDs was not an essential feature of persistent GHD, as almost onequarter of patients with history of isolated GHD had persistent GHD (overall, 11/45 [24\%]; organic, 4/4 [100\%]; idiopathic, 7/41 [17\%]: Figure 1). As a corollary, 11/38 patients (29\%) with reconfirmed GHD had childhood history of isolated GHD (organic and idiopathic combined).

Because history of organic hypothalamic-pituitary disorder had 100\% PPV for persistent GHD during transition, results for predictive value of IGF-I SDS, IGFBP-3 SDS, age at original diagnosis, body weight, and BMI are presented below only for the 55 patients with history of IGHD.

\section{Patients with idiopathic GH deficiency}

IGF-I and IGFBP-3 As reported above, 20 of 55 (36\%) patients with history of IGHD had peak $<5 \mu \mathrm{g} / \mathrm{L}$ at

Table 2 Predictors of persistent GH deficiency: all patients $(n=73)$

\begin{tabular}{|c|c|c|c|c|c|c|c|c|}
\hline & $\begin{array}{l}\text { History of } \\
\text { organic disease }\end{array}$ & $\begin{array}{l}\geq 2 \text { extra } \\
\text { PHDs }\end{array}$ & $\begin{array}{l}\geq 1 \text { extra } \\
\text { PHD }\end{array}$ & $\begin{array}{l}\text { IGF-I }< \\
-5.3 \text { SDS }\end{array}$ & $\begin{array}{l}\mid \text { IGF-I }< \\
-3.0 \text { SDS }\end{array}$ & $\begin{array}{l}\text { IGF-I }< \\
-2.0 \text { SDS }\end{array}$ & $\begin{array}{l}\geq 1 \text { extra PHD and } \\
\text { IGF-I }<-2.0 \text { SDS }\end{array}$ & $\begin{array}{l}\text { IGFBP-3< } \\
-2.0 \text { SDS }\end{array}$ \\
\hline $\begin{array}{l}\text { Positive Predictive } \\
\text { Value (\%) }\end{array}$ & 100 & 100 & 96 & 100 & 84 & 65 & 100 & 100 \\
\hline $\begin{array}{l}\text { Negative Predictive } \\
\text { Value (\%) }\end{array}$ & 64 & 66 & 76 & 71 & 83 & 84 & 75 & 59 \\
\hline Specificity (\%) & 100 & 100 & 97 & 100 & 83 & 46 & 100 & 100 \\
\hline Sensitivity (\%) & 47 & 53 & 71 & 63 & 84 & 92 & 68 & 37 \\
\hline
\end{tabular}

Abbreviations: IGF-I = insulin-like growth factor I, IGFBP-3 = insulin-like growth factor binding protein 3, $n=$ number, $P H D=$ pituitary hormone deficiency, $S D S=$ standard deviation score. 
retest. Mean serum IGF-I concentrations were subnormal (both as absolute values and as SDS) in patients with peak $\mathrm{GH}<5 \mu \mathrm{g} / \mathrm{L}$ (Table 1); however, the range of IGF-I SDS values was wide $(-1.6$ to -11.1 ; Table 1 , Figure $3 a)$. Mean IGF-I SDS was lower for female than for male patients with persistent GHD $(-7.68 \pm 2.54$ vs. $-4.65 \pm 2.19$, $\mathrm{p}=0.04)$. There was a strong correlation between IGF-I SDS and peak GH $\left(\mathrm{n}=54, \mathrm{r}_{\mathrm{s}}=0.67, \mathrm{p}<0.0001\right)$ primarily driven by the lower IGF-I SDS values. For idiopathic patients with peak $\mathrm{GH}<5 \mu \mathrm{g} / \mathrm{L}$ at retest, the correlation was modest but did not quite reach statistical significance: $\mathrm{n}=20, \mathrm{r}_{\mathrm{s}}=0.43, \mathrm{p}=0.06$; for those with $\mathrm{GH} \geq$ $5 \mu \mathrm{g} / \mathrm{L}$ the correlation was lower and non-significant: $\mathrm{n}=34, \mathrm{r}_{\mathrm{s}}=0.20, \mathrm{p}=0.26$.

Although two thirds of patients with history of IGHD (36/54 [67\%]; value missing for 1 patient) had subnormal serum IGF-I (<-2.0 SDS) at retesting, this threshold did not discriminate well between those who retested with peak GH above $(\mathrm{n}=35)$ or below $(\mathrm{n}=20) 5 \mu \mathrm{g} / \mathrm{L}$ (specificity 50\%; Table 3 ). Therefore, different threshold values of IGF-I SDS were examined to determine the cut-off that provided optimal predictive power. Whereas only $19 / 36(53 \%)$ of idiopathic patients with IGF-I $<-2.0$ SDS had peak $\mathrm{GH}<5 \mu \mathrm{g} / \mathrm{L}$ at retest, PPV increased to $73 \%$ at -3.0 SDS, $81 \%$ at -4.0 SDS, and $100 \%$ at -5.3 SDS (Table 3). However, at this very low cutoff, sensitivity was only $55 \%$ because 9 idiopathic patients who retested as GH deficient had IGF-I SDS greater than this threshold (Figure 3a). Notably, only 1 idiopathic patient who retested as GH deficient had IGF-I > -2.0 SDS, and none had IGF-I > -1.6 SDS; thus IGF-I > -1.6 SDS had $100 \%$ NPV for GHD (Table 3, Figure 3a).

In general, mean IGFBP-3 concentrations were closer to average for age/sex than IGF-I in the idiopathic cohort (Table 1), but were somewhat lower for female than male patients (for patients with persistent GHD: female, $-1.86 \pm 2.39$; male, $-0.77 \pm 1.56$; $\mathrm{p}=0.28$ ). Subnormal IGFBP-3 was more predictive of persistent GHD than subnormal IGF-I in this group, as all idiopathic patients with IGFBP-3 $<-2.0$ SDS had peak $\mathrm{GH}<5 \mu \mathrm{g} / \mathrm{L}$ on retest (PPV 100\%; Table 3, Figure 3b).

Age at original diagnosis Young age $(<4$ years $)$ at diagnosis of childhood IGHD was a strong predictor of persistent GHD in this group, with $97 \%$ specificity and 89\% PPV (Table 3). On average patients with history of IGHD who later retested as GH deficient were less than half the age at original diagnosis of those who retested as non-GH deficient $(4.5 \pm 3.2$ vs. $10.5 \pm 3.3$ years, $\mathrm{p}<0.0001$; Table 1, Figure 4). IGHD patients with persistent GHD therefore had received GH treatment for twice as long as those who retested as non-GH deficient and those with organic GHD (Table 1).
Sex, body weight, and BMI The proportion of patients with history of IGHD who had persistent GHD at retest was similar for male and female patients (13/33 [39\%] vs. $7 / 22$ [32\%]). Body weight and BMI at retest were significantly greater in patients with persistent GHD than in those with peak $\mathrm{GH} \geq 5 \mu \mathrm{g} / \mathrm{L}$ ( $\mathrm{p}<0.01$ ), demonstrating modest but significant inverse correlations with peak GH (BMI vs. peak GH: $\mathrm{n}=54, \mathrm{r}_{\mathrm{s}}=-0.39, \mathrm{p}=0.003$ ) and with IGF-I SDS (BMI vs. IGF-I SDS: $n=54$, $\left.\mathrm{r}_{\mathrm{s}}=-0.31, \mathrm{p}=0.02\right)$. Although there was a wide range of BMI values $\left(18.6-37.4 \mathrm{~kg} / \mathrm{m}^{2}\right)$ in idiopathic patients with persistent GHD, all patients with BMI $>30 \mathrm{~kg} / \mathrm{m}^{2}$ had peak $\mathrm{GH}<5 \mu \mathrm{g} / \mathrm{L}$ at retest (Figure 3c).

Because overweight and obesity may blunt GH secretion even in non-GH-deficient individuals, we specifically evaluated all idiopathic patients who had $\mathrm{GH}$ stimulation test results consistent with persistent GHD and had BMI $>25 \mathrm{~kg} / \mathrm{m}^{2}$ (World Health Organization definition of overweight) at retesting. Of 12 such patients, 10 had additional PHDs, and therefore had independent factors strongly predictive of persistent GHD (93\% PPV), irrespective of BMI. The 2 overweight patients with isolated IGHD whose GH responses could potentially have been blunted by being overweight, were only mildly overweight and had peak $\mathrm{GH}$ values $<1 \mu \mathrm{g} / \mathrm{L}$ (patient 1: BMI $26 \mathrm{~kg} / \mathrm{m}^{2}$, peak GH $0.70 \mu \mathrm{g} / \mathrm{L}$; patient 2: BMI $28 \mathrm{~kg} / \mathrm{m}^{2}$, peak GH $\left.0.26 \mu \mathrm{g} / \mathrm{L}\right)$. Therefore, given these extremely low peak GH concentrations, it seems unlikely that either of these patients was misclassified as $\mathrm{GH}$ deficient due to obesity-related blunting of $\mathrm{GH}$ secretion. Overall, neither weight nor BMI was a good predictor of persistent GHD (e.g. PPV 36\% for BMI $38 \mathrm{~kg} / \mathrm{m}^{2}$ ).

\section{Discussion}

Since the early 1990s the role of GH in many physiologic processes in adulthood has become clearer, and the importance of $\mathrm{GH}$ replacement for $\mathrm{GH}$-deficient adults is well established [19-21,34]. Many studies have demonstrated deficits in somatic and metabolic maturation in GH-deficient individuals untreated during the transition period [1-4,6-17]. However, the determination of precisely which patients require ongoing $\mathrm{GH}$ therapy has been less clear, as many patients treated for childhood GHD do not fulfill diagnostic criteria for adult GHD after completion of linear growth. This finding may reflect a number of factors, including differences in diagnostic criteria for GHD in childhood $v s$. adulthood, lack of reproducibility of $\mathrm{GH}$ stimulation tests, and perhaps sex steroid-mediated maturational changes in hypothalamic control of $\mathrm{GH}$ secretion during puberty [23,35-37]. Consequently, retesting GH secretion in adolescents and young adults with childhood-onset GHD is generally recommended [19-22]. However, such 

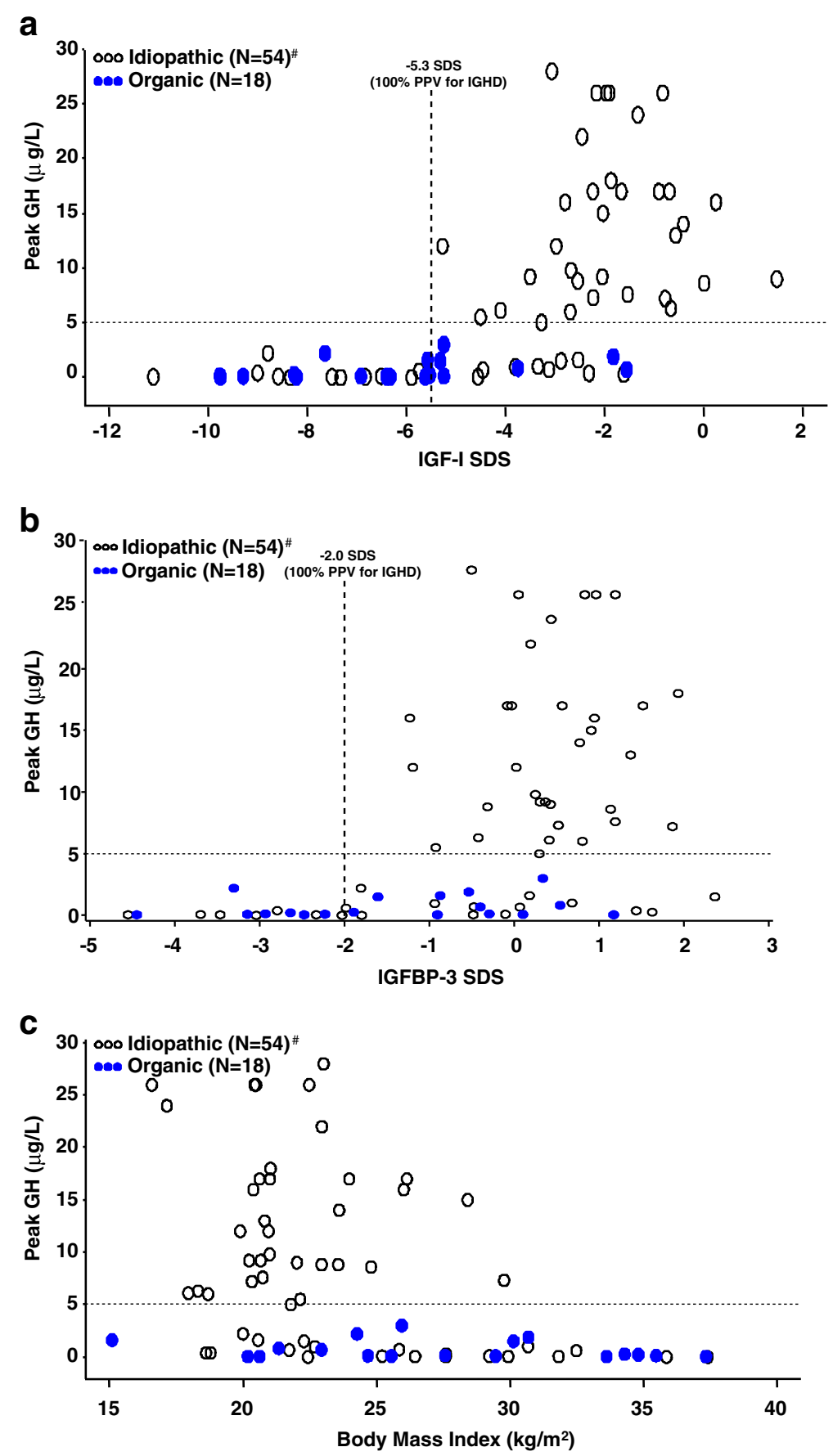

Figure 3 a. Relationship between IGF-I SDS and peak GH response. Dashed vertical line represents the IGF-I threshold of -5.3 SDS, which provides 100\% PPV for the diagnosis of persistent GH deficiency in patients with IGHD. IGF-I = insulin-like growth factor -l; b. Relationship between IGFBP-3 SDS and peak GH response. Dashed vertical line represents the IGFBP-3 threshold of - 2.0 SDS, which provides $100 \%$ PPV for the diagnosis of persistent GH deficiency in patients with IGHD. IGFBP-3 = insulin-like growth factor binding protein 3; c. Relationship between body mass index and peak GH response. For the idiopathic group, Spearman $r=-0.39, p=0.003$. There was no significant correlation for the organic group. Notes and abbreviations: See "Results" for listing of stimulation tests used; \#One outlier idiopathic patient with a peak GH of $57 \mu \mathrm{g} / \mathrm{L}$ was excluded to avoid undue influence on the correlation and compressing the vertical axis. $G H=$ growth hormone; IGHD =idiopathic GH deficiency; $\mathrm{N}=$ total number of patients in each category (organic vs. idiopathic); PPV = positive predictive value; SDS = standard deviation score. 
Table 3 Predictors of persistent GH deficiency in patients with history of idiopathic GH deficiency $(\mathbf{n}=55)$

\begin{tabular}{|c|c|c|c|c|c|c|c|c|c|c|c|}
\hline & $\begin{array}{l}\geq 1 \text { cextra } \\
\text { PHD }\end{array}$ & $\begin{array}{l}\geq 2 \text { extra } \\
\text { PHD }\end{array}$ & $\begin{array}{l}\text { IGF-I < } \\
-5.3 \text { SDS }\end{array}$ & $\begin{array}{l}\text { IGF-I < } \\
-4.0 \text { SDS }\end{array}$ & $\begin{array}{l}\text { IGF-I < } \\
-3.0 \text { SDS }\end{array}$ & $\begin{array}{l}\text { IGF-I < } \\
-2.0 \text { SDS }\end{array}$ & $\begin{array}{l}\text { IGF-I > } \\
-1.6 \text { SDS }\end{array}$ & $\begin{array}{l}\text { IGFBP-3< } \\
-2.0 \text { SDS }\end{array}$ & $\begin{array}{l}\text { Age }<4 \mathrm{yr} \text { at } \\
\text { original } \mathrm{Dx}\end{array}$ & $\begin{array}{l}\geq 1 \text { PHD } \\
+ \text { IGF-I } \\
-2.0 \text { SDS }\end{array}$ & $\begin{array}{l}\text { IGF-I }<-2.0 \\
\text { SDS }+ \text { age } \\
<4 \mathrm{yr} \text { at } \\
\text { original Dx }\end{array}$ \\
\hline $\begin{array}{l}\text { Positive } \\
\text { Predictive } \\
\text { Value (\%) }\end{array}$ & 93 & 100 & 100 & 81 & 73 & 53 & 49 & 100 & 89 & 100 & 100 \\
\hline $\begin{array}{l}\text { Negative } \\
\text { Predictive } \\
\text { Value (\%) }\end{array}$ & 83 & 78 & 79 & 82 & 88 & 94 & 100 & 73 & 76 & 83 & 75 \\
\hline Specificity (\%) & 97 & 100 & 100 & 91 & 82 & 50 & 38 & 100 & 97 & 100 & 100 \\
\hline Sensitivity (\%) & 65 & 50 & 55 & 65 & 80 & 95 & 100 & 35 & 42 & 65 & 40 \\
\hline
\end{tabular}

Abbreviations: $D x=$ diagnosis, $G H=$ growth hormone, $I G F-I=$ insulin-like growth factor $\mathrm{I}, n=$ number, $P H D=$ pituitary hormone deficiency, $S D S=$ standard deviation score, $y r=$ year.

testing requires interruption of $\mathrm{GH}$ therapy, and the results vary by protocol, secretagogue, and $\mathrm{GH}$ assay; lack reproducibility; and do not predict treatment response [23]. Furthermore, the increasingly limited availability of many agents for which $\mathrm{GH}$ stimulation testing protocols are established (e.g. arginine, GH-releasing hormone, L-dopa) leaves few options other than ITT, which requires physician presence because of the risk of complications such as seizures as a result of significant hypoglycemia [24,33]. Therefore, this study aimed to provide a rational basis for $\mathrm{GH}$ stimulation retesting in US patients by examining factors predictive of persistent GHD in a cohort of 73 patients with history of childhoodonset GHD who underwent centralized measurements of IGF-I, IGFBP-3, and GH after completion of childhood treatment. Because of limited published information, particular attention was focused on factors predictive of persistence in patients with history of IGHD, the most common form of childhood GHD treated in the USA.
Our finding that $100 \%$ of US patients with history of organic GHD had persistent GHD confirms previous European reports [26,27,30,38,39]. Similarly, we found a very high prevalence of persistent GHD in patients with $\geq 1$ additional PHD (96\% PPV) [25,29,40-42]. Thus it appears that despite potential differences between US and European physicians with regard to diagnosis and treatment of childhood GHD, the key factors associated with its persistence appear consistent across these geographies. The single patient with an additional PHD (TSH) who did not fulfill the study definition of GHD may nevertheless have a partial GH secretory defect because peak $\mathrm{GH}$ response to arginine/L-dopa was $9.0 \mu \mathrm{g} / \mathrm{L}$. Other studies have concluded that such patients may have a milder form of GH "insufficiency" [29,43-45]. As GH is usually the first anterior pituitary hormone affected by pathological insults, there is a biological rationale to suspect that patients with $\geq 1$ additional PHD will likely have persistent GHD [46,47].

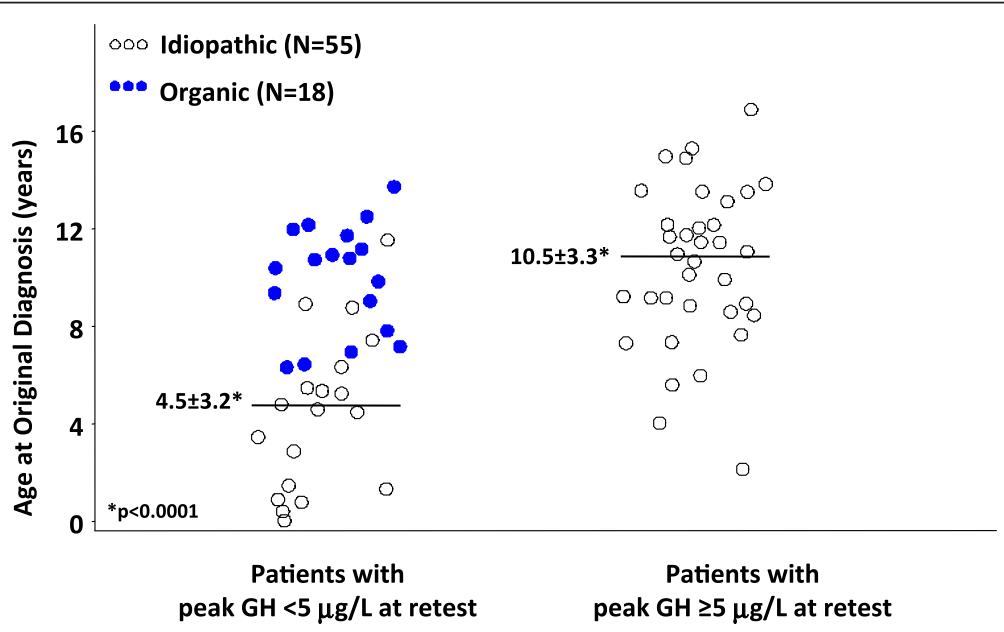

Figure 4 Age at original childhood diagnosis of GH deficiency. Distribution of age at original diagnosis for patients who retested as $\mathrm{GH}$ deficient (left) vs. those who retested as GH sufficient (right). Within the persistently GH-deficient group, patients with history of idiopathic GH deficiency were significantly younger at diagnosis than those with history of organic GH deficiency (Table 1). Horizontal lines represent mean ages at initial diagnosis for patients with history of IGHD. GH = growth hormone; $\mathrm{N}=$ total number of patients in each category (organic vs. idiopathic). 
Organic etiology of GHD and presence of additional PHDs reflect the severity of hypothalamic-pituitary dysfunction, so it is not surprising that severe GHD persisted in almost all such patients; provocative $\mathrm{GH}$ retesting thus appears unnecessary in patients with organic disease $[29,38,39,42]$. Instead, GH potentially could be continued uninterrupted through the transition period (with appropriate dosage adjustment) to avoid the adverse changes in body composition, lipid profile, and cardiac function that may develop following discontinuation of GH [1-4,6-17]. Furthermore, patient care could potentially be improved by providing the family with a clear expectation at the initiation of childhood treatment, of the likelihood that GH treatment will be required in adulthood.

Although only half of our patients with MPHD had a childhood diagnosis of organic disease, some patients whose MPHD was labeled "idiopathic" may, in fact, have had an undiagnosed genetic disorder. This is suggested in other studies by the presence of mutations in genes encoding pituitary transcription factors, most commonly $P R O P 1$, in up to half of patients with an original diagnosis of idiopathic MPHD [37,48-51]. Furthermore, up to one-quarter of children with isolated GHD may have detectable genetic defects $[49,52,53]$. Thus, genetic studies should be obtained whenever possible in any patient with MPHD or early-onset isolated GHD, because presence of a mutation would obviate the need for $\mathrm{GH}$ stimulation retesting after childhood treatment, and allow such patients to continue replacement therapy uninterrupted. Similarly, although our study did not include magnetic resonance imaging (MRI) assessment, MRI anomalies have been reported as a significant predictor of persistent GHD during transition [27,37,41,54], and certain MRI findings may indicate a genetic basis for hypothalamic-pituitary disorders [55-57].

In contrast to those with organic hypothalamicpituitary dysfunction, patients with childhood IGHD present a substantial diagnostic dilemma, and prior studies have not evaluated predictive factors for persistent GHD in this specific population. Moreover, as idiopathic patients represent the majority of recipients of childhood GH treatment in the USA [58-60], they constitute the bulk of the clinical load for US pediatric endocrinologists. Therefore, our study specifically examined factors predictive of persistent GHD in this subgroup. Only about one-third of idiopathic patients (36\%) retested as GH deficient; this was true for even fewer patients with isolated IGHD (17\%). The low rate of persistent GHD in our US idiopathic cohort is similar to the rates reported in Belgian, British, and French studies, in which 15\%-24\% patients with childhood isolated IGHD remained GH deficient when retested $[26,40,61]$. However, our results differ notably from those of an Italian study in which
$52 \%-65 \%$ of young adults with isolated IGHD were GH deficient on retest, likely reflecting the fact that about one-third of patients in the Italian study had severe childhood GHD [39].

Apart from the presence of additional PHDs, the strongest independent predictor of persistent GHD in our idiopathic cohort was the finding of IGFBP-3 below -2.0 SDS, which had 100\% PPV for persistent GHD. In contrast, a subnormal IGF-I value (i.e. $<-2.0 \mathrm{SDS}$ ) was not prognostically helpful in those with history of IGHD, as only half of such patients retested as GH deficient. However, an extremely low IGF-I (<-5.3 SDS) provided $100 \%$ PPV; in addition, the combination of IGF-I SDS below -2.0 and young age at original diagnosis of IGHD was strongly predictive of persistent GHD. Our finding of lack of predictive power of subnormal IGF-I contrasts with the good concordance between IGF-I and peak GH reported in European studies [25-27,55], perhaps reflecting the typically greater severity of GHD in European children, differences in agents and diagnostic cut-points used for $\mathrm{GH}$ testing, and time between discontinuation of $\mathrm{GH}$ and retesting (as GHD may manifest after increasing time off treatment $[43,44])$. Furthermore, IGF-I secretion is controlled by other factors in addition to $\mathrm{GH}$, such as nutritional status and sex steroid milieu $[32,62,63]$. Perhaps more importantly, IGF-I may provide a good screen for GH sufficiency, as $100 \%$ of idiopathic patients who had IGF-I > -1.6 SDS were GH sufficient on retest (100\% NPV for GHD). Patients with IGF-I SDS values above this level after discontinuation of GH treatment could be spared the invasive process of GH stimulation retesting after completion of childhood therapy, as all would be expected to be GH sufficient, and instead could be followed clinically.

The other useful predictor of persistent GHD in the idiopathic cohort was age $<4$ years at original diagnosis (specificity 97\%, PPV 89\%), likely reflecting the fact that growth failure occurs earlier in children with more severe GHD [29]. Consequently, families of children who are very young at initial diagnosis of IGHD should be forewarned of the likelihood of its permanence.

This study has a number of potential limitations. First, no direct comparison of $\mathrm{GH}$ stimulation test results at the time of childhood diagnosis versus results on retest in the present study could be made because initial testing was performed at the individual institutions and not at a central laboratory. For the same reason, we were unable to assess the predictive value of a number of other clinically relevant parameters, such as pretreatment IGF-I, height SDS, height velocity, or height gain in response to childhood treatment. Second, the single cut-point of $5 \mu \mathrm{g} / \mathrm{L}$ defined in the protocol to represent the threshold for $\mathrm{GH}$ deficiency irrespective of the testing agent used, may be considered to lack precision; a subsequent study in patients with adult-onset GHD (conducted after our 
study was designed and implemented) indicates that different diagnostic thresholds are appropriate for different agents [33]. However, evidence for the appropriateness of this approach is lacking for patients in the transition period, as noted by consensus statements from endocrine societies [19-21]. Third, because our study population comprised patients screened for aGH replacement trial, the cohort may represent the more severe end of the US childhood GHD spectrum, and persistent GHD may be less likely in milder cohorts. Nevertheless, our finding that only $17 \%$ of patients with history of isolated IGHD had persistent GHD is consistent with European data for this subgroup. Fourth, IGF-I assays have substantial interlaboratory variability, so the very low IGF-I SDS values predictive of persistent GHD in our study may not be applicable to IGF-I measured elsewhere. Fifth, obesity is associated with blunted $\mathrm{GH}$ response to stimulation, even in non-GH-deficient individuals [64], leading to potential bias toward overdiagnosis of GHD. Thus the peak GH threshold of $5 \mu \mathrm{g} / \mathrm{L}$ used for diagnosis of GHD in this study may be inadequately stringent for obese patients (BMI > $30 \mathrm{~kg} / \mathrm{m}^{2}$ ) [20]. Nevertheless, as all obese patients in this study had additional PHDs, misdiagnosis due to obesity-related blunting of GH secretion seems unlikely. Finally, it is acknowledged that no single study can provide comprehensive guidelines for the broad range of patients treated and followed in different clinical settings, and assessment should be individualized for each patient.

\section{Conclusions}

This US study demonstrates that patients with an organic basis for childhood-onset GHD and those with $\geq 2$ additional PHDs may not require GH stimulation testing after completion of linear growth for confirmation of persistent GHD and potentially could continue GH treatment without interruption. However, as most children treated in the USA have an idiopathic, isolated form of GHD, the majority will likely not require GH treatment during adulthood. In patients with history of IGHD, the strongest predictor of persistent GHD was subnormal IGFBP-3 SDS $(<-2.0$ SDS), whereas subnormal IGF-I ( $<-2.0$ SDS) lacked predictive power. Conversely, posttreatment IGF-I $>-1.6$ SDS was predictive of GH sufficiency. Therefore, unless IGF-I is extremely low (<-5.3 SDS) accompanied by subnormal IGFBP-3 (<-2.0 SDS), patients with IGHD should undergo $\mathrm{GH}$ retesting after completion of childhood treatment.

\section{Competing interests}

This study was sponsored by Eli Lilly and Company (Indianapolis, IN). In compliance with the Uniform Requirements for Manuscripts, established by the International Committee of Medical Journal Editors, the sponsor did not impose any impediment, directly or indirectly, on the publication of the results of this study.

\section{Authors' contributions}

CAQ and JJC conceived the objectives questions and analyses reported in this manuscript; CAQ coordinated the study and manuscript development, and drafted the manuscript; $A J Z$ and $C C L$ participated in the design of the analyses and performed the statistical analyses; DMB, CH, LL, DRR, and ET revised the manuscript for intellectual content. All authors read and approved the final manuscript.

\section{Acknowledgments}

The authors thank the patients and the other investigators of the Lilly US GH Deficiency Transition Study Group for their participation in this study, and thank Drs. Heike Jung, Mark L. Hartman, and Alan G. Zimmerman for critical review of the manuscript. The authors acknowledge medical writing assistance provided by ProScribe Medical Communications whose services complied with international guidelines for Good Publication Practice.

\section{Author details}

'Lilly Research Laboratories, Indianapolis, IN 46285, USA. ${ }^{2}$ Allergan, Inc, Irvine, CA 92612, USA. ${ }^{3}$ Division of Pediatric Endocrinology, University of Minnesota, Minneapolis, MN 55455, USA. ${ }^{4}$ Children's Mercy Hospital, Kansas City, MO 64108, USA. ${ }^{5}$ MassGeneral Hospital for Children, Boston, MA 02114, USA. ${ }^{6}$ Nationwide Children's Hospital, Columbus, OH 43205, USA. ${ }^{7}$ University of lowa, Children's Hospital of lowa, lowa City, IA 52242, USA. ${ }^{8}$ Lilly Research Laboratories, Indianapolis, IN 46285, USA.

Received: 25 October 2012 Accepted: 30 January 2013

Published: 13 February 2013

\section{References}

1. Rutherford OM, Jones DA, Round JM, Buchanan CR, Preece MA: Changes in skeletal muscle and body composition after discontinuation of growth hormone treatment in growth hormone deficient young adults. Clin Endocrinol 1991, 34(6):469-475.

2. Colle M, Auzerie J: Discontinuation of growth hormone therapy in growth-hormone-deficient patients: assessment of body fat mass using bioelectrical impedance. Horm Res 1993, 39(5-6):192-196.

3. Ogle GD, Moore B, Lu PW, Craighead A, Briody JN, Cowell CT: Changes in body composition and bone density after discontinuation of growth hormone therapy in adolescence: an interim report. Acta Paediatr Suppl 1994, 399:3-7.

4. Attanasio AF, Lamberts SW, Matranga AM, Birkett MA, Bates PC, Valk NK, Hilsted J, Bengtsson BA, Strasburger CJ: Adult growth hormone (GH)deficient patients demonstrate heterogeneity between childhood onset and adult onset before and during human GH treatment, Adult Growth Hormone Deficiency Study Group. J Clin Endocrinol Metab 1997, 82:82-88,

5. Gullestad L, Birkeland K, Bjonerheim R, Djoseland O, Trygstad O, Simonsen S: Exercise capacity and hormonal response in adults with childhood-onset growth hormone deficiency during long-term somatropin treatment. $G H$ and IGF-I Res 1998, 8:377-384.

6. Cowan FJ, Evans WD, Gregory JW: Metabolic effects of discontinuing growth hormone treatment. Arch Dis Child 1999, 80(6):517-523.

7. Johannsson G, Albertsson-Wikland K, Bengtsson BA: Discontinuation of growth hormone $(\mathrm{GH})$ treatment: metabolic effects in $\mathrm{GH}$-deficient and $\mathrm{GH}$-sufficient adolescent patients compared with control subjects, Swedish Study Group for Growth Hormone Treatment in Children. J Clin Endocrinol Metab 1999, 84:4516-4524.

8. Hulthen L, Bengtsson BA, Sunnerhagen KS, Hallberg L, Grimby G, Johannsson G: GH is needed for the maturation of muscle mass and strength in adolescents. J Clin Endocrinol Metab 2001, 86(10):4765-4770.

9. Attanasio AF, Howell S, Bates PC, Frewer P, Chipman J, Blum WF, Shalet SM: Body composition, IGF-I and IGFBP-3 concentrations as outcome measures in severely GH-deficient (GHD) patients after childhood GH treatment: a comparison with adult onset GHD patients. I Clin Endocrinol Metab 2002, 87(7):3368-3372.

10. Colao A, Di Somma C, Salerno M, Spinelli L, Orio F, Lombardi G: The cardiovascular risk of GH-deficient adolescents. J Clin Endocrinol Metab 2002, 87(8):3650-3655.

11. Drake WM, Carroll PV, Maher KT, Metcalfe KA, Camacho-Hübner C, Shaw NJ, Dunger DB, Cheetham TD, Savage MO, Monson JP: The effect of cessation of growth hormone $(\mathrm{GH})$ therapy on bone mineral accretion in $\mathrm{GH}$ - 
deficient adolescents at the completion of linear growth. J Clin Endocrinol Metab 2003, 88(4):1658-1663.

12. Shalet SM, Shavrikova E, Cromer M, Child CJ, Keller E, Zapletalová J, Moshang T, Blum WF, Chipman JJ, Quigley CA, Attanasio AF: Effect of growth hormone $(\mathrm{GH})$ treatment on bone in postpubertal $\mathrm{GH}$-deficient patients: a 2-year randomized, controlled, dose-ranging study. J Clin Endocrinol Metab 2003, 88:4124-4129.

13. Tauber M, Jouret B, Cartault A, Lounis N, Gayrard M, Marcouyeux C, Pienkowski C, Oliver I, Moulin P, Otal P, Joffre F, Arnaud C, Rochiccioli P: Adolescents with partial growth hormone (GH) deficiency develop alterations of body composition after $\mathrm{GH}$ discontinuation and require follow-up. J Clin Endocrinol Metab 2003, 88(11):5101-5106.

14. Underwood LE, Attie KM, Baptista J, Genentech Collaborative Study Group: Growth hormone $(\mathrm{GH})$ dose-response in young adults with childhoodonset GH deficiency: a two-year, multicenter, multiple-dose, placebocontrolled study. J Clin Endocrinol Metab 2003, 88(11):5273-5280.

15. Attanasio AF, Shavrikova E, Blum WF, Cromer M, Child CJ, Paskova M, Lebl J, Chipman JJ, Shalet SM, Hypopituitary Developmental Outcome Study Group: Continued growth hormone (GH) treatment after final height is necessary to complete somatic development in childhood-onset GHdeficient patients. J Clin Endocrinol Metab 2004, 89:4857-4862.

16. Carroll PV, Drake WM, Maher KT, Metcalfe K, Shaw NJ, Dunger DB, Cheetham TD, Camacho-Hübner C, Savage MO, Monson JP: Comparison of continuation or cessation of growth hormone $(\mathrm{GH})$ therapy on body composition and metabolic status in adolescents with severe $\mathrm{GH}$ deficiency at completion of linear growth. J Clin Endocrinol Metab 2004, 89:3890-3895

17. Koltowska-Haggstrom M, Geffner ME, Jonsson P, Monson JP, Abs R, Hana V, Hoybe C, Wollmann HA: Discontinuation of growth hormone (GH) treatment during the transition phase is an important factor determining the phenotype of young adults with nonidiopathic childhood-onset $\mathrm{GH}$ deficiency. J Clin Endocrinol Metab 2010, 95:2646-2654.

18. Shalet SM: Stepping into adulthood: The transition period. Horm Res 2004, 62(Suppl 4):15-22

19. Ho KKY, on behalf of the $2007 \mathrm{GH}$ Deficiency Consensus Workshop Participants: Consensus guidelines for the diagnosis and treatment of adults with GH deficiency II: a statement of the GH Research Society in association with the European Society for Pediatric Endocrinology, Lawson Wilkins Society, European Society of Endocrinology, Japan Endocrine Society, and Endocrine Society of Australia. Eur J Endocrinol 2007, 157:695-700.

20. Molitch ME, Clemmons DR, Malozowski S, Merriam GR, Vance ML: Evaluation and treatment of adult growth hormone deficiency: an Endocrine Society clinical practice guideline. J Clin Endocrinol Metab 2011, 96:1587-1609.

21. Cook DM, Yuen KCJ, Biller BMK, Kemp SF, Vance ML: American Association of Clinical Endocrinologists medical guidelines for clinical practice for growth hormone use in growth hormone-deficient adults and transition patients. Endocr Pract 2009, 15(Suppl 2):1-29.

22. Radovick S, DiVall S: Approach to the growth hormone-deficient child during transition to adulthood. J Clin Endocrinol Metab 2007, 92:1195-1200

23. Cacciari E, Tassoni P, Cicognani A, Pirazzoli P, Salardi S, Balsamo A, Cassio A, Zucchini S, Colli C, Tassinari D: Value and limits of pharmacological and physiological tests to diagnose growth hormone (GH) deficiency and predict therapy response: first and second retesting during replacement therapy of patients defined as GH deficient. J Clin Endocrinol Metab 1994, 79(6):1663-1669.

24. Yuen KCJ, Biller BMK, Molitch ME, Cook DE: Is lack of recombinant growth hormone (GH)-releasing hormone in the United State a setback or time to consider glucagon testing for adult GH deficiency? J Clin Endocrinol Metab 2009, 94:2702-2707.

25. Juul A, Kastrup KW, Pedersen SA, Skakkebaek NE: Growth hormone (GH) provocative retesting of 108 young adults with childhood-onset $\mathrm{GH}$ deficiency and the diagnostic value of insulin-like growth factor I (IGF-I) and IGF-binding protein-3. J Clin Endocrinol Metab 1997, 82:1195-1201.

26. Tauber M, Moulin P, Pienkowski C, Jouret B, Rochiccioli P: Growth hormone $(\mathrm{GH})$ retesting and auxological data in $131 \mathrm{GH}$-deficient patients after completion of treatment. J Clin Endocrinol Metab 1997, 82:352-356.

27. Maghnie M, Strigazzi C, Tinelli C, Autelli M, Cisternino M, Loche S, Severi F: Growth hormone (GH) deficiency (GH deficiency) of childhood onset: reassessment of $\mathrm{GH}$ status and evaluation of the predictive criteria for permanent GH deficiency in young adults. J Clin Endocrinol Metab 1999, 84:1324-1328

28. Adan L, Trivin C, Sainte-Rose C, Zucker JM, Hartmann O, Brauner R: GH deficiency caused by cranial irradiation during childhood: factors and markers in young adults. J Clin Endocrinol Metab 2001, 86:5245-5251.

29. Brabant G, Rasmussen AK, Biller BMK, Buchfelder M, Feldt-Rasmussen U, Forssmann K, Jonsson B, Koltowska-Haggstrom M, Maiter D, Saller B, Toogood A: Clinical implications of residual growth hormone (GH) response to provocative testing in adults with severe $\mathrm{GH}$ deficiency. J Clin Endocrinol Metab 2007, 92:2604-2609.

30. Secco A, di lorgi N, Napoli F, Calandra E, Calcagno A, Ghezzi M, Frassinetti C, Fratangeli N, Parodi S, Benassai M, Leitner Y, Gastaldi R, Lorini R, Maghnie M, Radetti G: Reassessment of growth hormone status in young adults with childhood-onset growth hormone deficiency: reappraisal of insulin tolerance testing. J Clin Endocrinol Metab 2009, 94:4195-4204.

31. Blum WF, Breier BH: Radioimmunoassays for IGFs and IGFBPs. Growth Regul 1994, 4(Suppl 1):11-19.

32. Blum WF, Schweizer R: Insulin-like growth factors and their binding proteins. In Diagnostics of Endocrine Function in Children and Adolescents. Edited by Ranke MB. Basel: Karger; 2003:166-199.

33. Biller BMK, Samuels MH, Zagar A, Cook DM, Arafah BM, Bonert V, Stavrou S, Kleinberg DL, Chipman JJ, Hartman ML: Sensitivity and specificity of six tests for the diagnosis of adult GH deficiency. J Clin Endocrinol Metab 2002, 87:2067-2079.

34. Simpson H, Savine R, Sönksen P, Bengtsson BA, Carlsson L, Christiansen JS, Clemmons D, Cohen P, Hintz R, Ho K, Mullis P, Robinson I, Strasburger C, Tanaka T, Thorner M, GRS Council: Growth hormone replacement therapy for adults: into the new millennium. GH \& IGF Res 2002, 12(1):1-33.

35. Wacharasindhu S, Cotterill AM, Camacho-Hubner C, Besser GM, Savage MO: Normal growth hormone secretion in growth hormone insufficient children retested after completion of linear growth. Clin Endocrinol 1996, 45(5):553-556.

36. Van den Broek J, Hering P, de Lely V, Hokken-Koelega A: Interpretive difficulties with growth hormone provocative retesting in childhoodonset growth hormone deficiency. Horm Res 1999, 51:1-9.

37. Dattani M, Preece M: Growth hormone deficiency and related disorders: insights into causation, diagnosis and treatment. Lancet 2004, 363:1977-1987.

38. Nicolson A, Toogood AA, Rahim A, Shalet SM: The prevalence of severe growth hormone deficiency in adults who received growth hormone replacement in childhood. Clin Endocrinol (Oxf) 1996, 44:311-316.

39. Aimaretti G, Baffoni C, Bellone S, Di Vito L, Corneli G, Arvat E, Benso L, Camanni $F$, Ghigo E: Retesting young adults with childhood-onset growth hormone $(\mathrm{GH})$ deficiency with $\mathrm{GH}$-releasing-hormone-plus-arginine test. J Clin Endocrinol Metab 2000, 85:3693-3699.

40. Toogood AA, Beardwell CG, Shalet SM: The severity of growth hormone deficiency in adults with pituitary disease is related to the degree of hypopituitarism. Clin Endocrinol 1994, 41(4):511-516.

41. Maghnie M, Salati B, Bianchi S, Rallo M, Tinelli C, Autelli M, Aimaretti G, Ghigo E: Relationship between the morphological evaluation of the pituitary and the growth hormone $(\mathrm{GH})$ response to $\mathrm{GH}$-releasing hormone plus arginine in children and adults with congenital hypopituitarism. J Clin Endocrinol Metab 2001, 86(4):1574-1579.

42. Hartman ML, Crowe BJ, Biller BMK, Ho KKY, Clemmons DR, Chipman JJ: Which patients do not require a GH stimulation test for the diagnosis of adult GH deficiency? J Clin Endocrinol Metab 2002, 87:477-485.

43. di lorgi N, Secco A, Napoli F, Tinelli C, Calcagno A, Fratangeli N, Ambrosini L, Rossi A, Lorini R, Maghnie M: Deterioration of growth hormone (GH) response and anterior pituitary function in young adults with childhoodonset GH deficiency and ectopic posterior pituitary: a two-year prospective follow-up study. J Clin Endocrinol Metab 2007, 92:3875-3884.

44. Gelwane G, Garel C, Chevenne D, Armoogum P, Simon D, Czernichow P, Léger J: Subnormal serum insulin-like growth factor levels in young adults with childhood-onset nonacquired growth hormone (GH) deficiency who recover normal GH secretion may indicate less severe but persistent pituitary failure. J Clin Endocrinol Metab 2007, 92:3788-3795.

45. Murray RD, Bidlingmaier M, Strasburger CJ, Shalet SM: The diagnosis of partial growth hormone deficiency in adults with a putative insult to the hypothalamo-pituitary axis. J Clin Endocrinol Metab 2007, 92:1705-1709.

46. Klibanski A: Nonsecreting pituitary tumors. Endocrinol Metab Clin North Am 1987, 16:793-804. 
47. Littley MD, Shalet SM, Beardwell CG, Ahmed SR, Applegate G, Sutton ML: Hypopituitarism following external radiotherapy for pituitary tumours in adults. Q J Med 1989, 70:145-160.

48. Bottner A, Keller E, Kratzsch J, Stobbe H, Weigel JFW, Keller A, Hirsch W, Kiess W, Blum WF, Pfäffle RW: PROP1 mutations cause progressive deterioration of anterior pituitary function including adrenal insufficiency: a longitudinal analysis. J Clin Endocrinol Metab 2004, 89(10): 5256-5265.

49. Pfaffle RW, Hunter CS, Savage JJ, Duran-Prado M, Mullen RD, Neeb ZP, Eiholzer U, Hesse V, Haddad NG, Stobbe HM, Blum WF, Weigel JFW, Rhodes SJ: Three novel missense mutations within the LHX4 gene are associated with variable pituitary hormone deficiencies. J Clin Endocrinol Metab 2008, 93(3):1062-1071.

50. Lebl J, Vosáhlo J, Pfaeffle RW, Stobbe H, Cerná J, Novotná D, Zapletalová J, Kalvachová B, Hána V, Weiss V, Blum WF: Auxological and endocrine phenotype in a population-based cohort of patients with PROP1 gene defects. Eur J Endocrinol 2005, 153(3):389-396.

51. Vieira TC, da Silva MR D, Cerutti JM Brunner E, Borges M, Arnaldi LT, Kopp P, Abucham J: Familial combined pituitary hormone deficiency due to a novel mutation R99Q in the hot spot region of prophet of Pit1 presenting as constitutional growth delay. J Clin Endocrinol Metab 2003, 88:38-44.

52. Hess O, Hujeirat Y, Wajnrajch MP, Allon-Shalev S, Zadik Z, Lavi I, Tenenbaum-Rakover $Y$ : Variable phenotypes in familial isolated growth hormone deficiency caused by a G6664A mutation in the GH-1 gene. J Clin Endocrinol Metab 2007, 92:4387-4393.

53. Pantel $P$, Legendre M, Nivot $S$, Morisset $S$, Vie-Luton M-P, le Bouc $Y$, Epelbaum J, Amselem S: Recessive isolated growth hormone deficiency and mutations in the ghrelin receptor. J Clin Endocrinol Metab 2009, 94:4334-4341

54. Leger J, Danner S, Simon D, Garel C, Czernichow P: Do all patients with childhood-onset growth hormone deficiency (GHD) and ectopic neurohypophysis have persistent GHD in adulthood? I Clin Endocrinol Metab 2005, 90(2):650-656.

55. Binder G, Nagel BH, Ranke MB, Mullis PE: Isolated GH deficiency (IGHD) type II: imaging of the pituitary gland by magnetic resonance reveals characteristic differences in comparison with severe IGHD of unknown origin. Eur J Endocrinol 2002, 147(6):755-760.

56. Osorio MGF, Marui S, Jorge AAL, Latronico AC, Lo LSS, Leite CC, Estefan V, Mendonca BB, Arnhold IJP: Pituitary magnetic resonance imaging and function in patients with growth hormone deficiency with and without mutations in GHRH-R, GH-1, or PROP-1 genes. J Clin Endocrinol Metab 2002, 87(11):5076-5084.

57. Dattani M: Growth hormone deficiency and combined pituitary hormone deficiency: does the genotype matter? Clin Endocrinol 2005, 63:121-130.

58. August GP, Lippe BM, Blethen SL, Rosenfeld RG, Seelig SA, Johanson AJ, Compton PG, Frane JW, McClellan BH, Sherman BM: Growth hormone treatment in the United States: demographic and diagnostic features of 2331 children. J Pediatr 1990, 116(6):899-903.

59. Root AW, Kemp SF, Rundle AC, Dana K, Attie KM: Effect of long-term recombinant growth hormone therapy in children-the National Cooperative Growth Study, USA, 1985-1994. J Pediatr Endocrinol 1998, 11(3):403-412.

60. Saenger P: A lifetime of growth hormone deficiency: a US pediatric perspective. J Pediatr Endocrinol 2000, 13(Suppl 6):1337-1342.

61. Thomas M, Massa G, Maes M, Beckers D, Craen M, Francois I, Heinrichs C, Bourguignon J-P, Belgian Study Group for Paediatric Endocrinology: Growth hormone (GH) secretion in patients with childhood-onset GH deficiency: retesting after one year of therapy and at final height. Horm Res 2003, 59:7-15.

62. Juul A: Serum levels of insulin-like growth factor I and its binding proteins in health and disease. GH and IGF Res 2003, 13:113-170.

63. Christoforidis A, Maniadaki I, Stanhope R: Growth hormone / insulin-like growth factor-1 axis during puberty. Pediatr Endocrinol Rev 2005, 3(1):5-10.

64. Kokkoris P, Pi-Sunyer FX: Obesity and endocrine disease. Endocrinol Metab Clin N Am 2003, 32(4):895-914.

doi:10.1186/1687-9856-2013-6

Cite this article as: Quigley et al:: United States multicenter study of factors predicting the persistence of $\mathrm{GH}$ deficiency during the transition period between childhood and adulthood. International Journal of Pediatric Endocrinology 2013 2013:6.

\section{Submit your next manuscript to BioMed Central and take full advantage of:}

- Convenient online submission

- Thorough peer review

- No space constraints or color figure charges

- Immediate publication on acceptance

- Inclusion in PubMed, CAS, Scopus and Google Scholar

- Research which is freely available for redistribution 